\title{
EFFECTIVENESS OF COUNSELING USING AUDIO VISUAL COMPARED WITH CONVENTIONAL COUNSELLING TO IMPROVE INTENTION TO VOLUNTARY COUNSELING AND TESTING IN HOUSEWIVES
}

\author{
Bani Dianika1), Tanjung Anitasari²), Anisa Catur Wijayanti²) \\ ${ }^{1)}$ Masters Program in Public Health, Universitas Sebelas Maret \\ 2)Departement of Public Health, Muhammadiyah University, Surakarta, Indonesia
}

\begin{abstract}
Background: The low uptake of HIV voluntary counselling and testing (VCT) has hindered global attempts to prevent new HIV infections and has limited scale-up of HIV care and treatment. However, less studies on the effectiveness of counseling method to establish the most effective method to increase the intention to VCT testing. The purpose of this study was to examine the effectiveness of counseling using audio visual compared with conventional counseling to improve intention to VCT in housewives.

Subjects and Method: This was a randomized controlled trial. A sample of 122 housewive women was selected for this study and divided into two groups: (1) 61 women received counseling using audio visual, and (2) 61 women received counseling without any media. The dependent variable was intention to VCT uptake. The independent variables were counseling using audio visual or without audio visual. Intention to VCT uptake before and after intervention were measured by questionnaire. Mean difference of intention to VCT uptake between groups was examined using independent t-test.
\end{abstract}

Results: After intervention, mean of intention to VCT uptake in the audio visual group (Mean $=32.77 ; \mathrm{SD}=3.84$ ) was higher than in the control group (Mean=30.44; $\mathrm{SD}=$ 2.55), and it was statistically significant ( $\mathrm{p}<0.005)$.

Conclusion: Counseling using audio visual improves intention to VCT uptake in housewive women higher than without audio visual.

Keywords: HIV/AIDS, voluntary counseling and testing, housewive, counseling, audio visual

\section{Correspondence:}

Bani Dianika. Masters Program in Public Health, Universitas Sebelas Maret. Jl. Ir. Sutami 36A, Surakarta 57126, Central Java. Email: banidianika@gmail.com. Mobile: o82227339349 